\title{
MODEL KEPEMIMPINAN INSTRUKSIONAL KEPALA SEKOLAH
}

\author{
Husaini Usman \\ Fakultas Teknik Universitas Negeri Yogyakarta \\ email: husainiusman@gmail.com
}

\begin{abstract}
Abstrak: Penelitian ini bertujuan untuk menemukan model kepemimpinan instruksional kepala sekolah. Penelitian ini menggunakan pendekatan kualitatif dengan jenis multikasus. Instrumen penelitan adalah peneliti sendiri. Teknik pengumpulan data yang digunakan adalah wawancara mendalam, observasi partisipasi, dan dokumentasi. Subjek penelitian adalah kepala sekolah, wakil kepala sekolah, dan guru secara snowball. Informan kunci dalam penelitian ini adalah kepala sekolah. Objek penelitian adalah pelaku, konsep, tempat, dan kegiatan. Langkah-langkah dan analisis data menggunakan model Creswell (2014). Keabsahan data dilakukan dengan kriteria kredibilitas, transferabilitas, dependabilitas, dan konfirmabilitas. Pada penelitian ditemukan model kepemimpinan instruksional kepala sekolah dengan siklus: pemahaman definisi kepemimpinan instruksional; tujuan dan manfaat kepemimpinan instruksional; indikator kepemimpinan instruksional yang efektif; strategi kepemimpinan instruksional; carapraktis melaksanakan kepemimpinan instruksional.
\end{abstract}

Kata Kunci: kepemimpinan, instruksional, kepala sekolah

\section{THE SCHOOL PRINCIPALS’ INSTRUCTIONAL LEADERSHIP MODEL}

\begin{abstract}
This study was aimed to find a school principals' instructional leadership model. This study used the multicase qualitative approach. The instrument was the researcher himself. The data were collected using the in-depth interviews, participant observation, and documentation. The subjects were the school principals, vice principals, and teachers taken using the snowball sampling technique. The key informants were the school principals. The object of the study was the persons, concept, places, and activities. The stages and the data analysis used Creswell's (2014) model. The data validation was carried out using the credibility, transferability, dependability, and confirmability criteria. The findings showed that the school principals' instructional model followed the following cycle: an understanding of the definition of instructional leadership, the objectives and benefits of instructional leadership, indicators of effective instructional leadership, and practical ways of implementing the instructional leadership.
\end{abstract}

Keywords: instructional, leadership, principal

\section{PENDAHULUAN}

Setiap manusia adalah pemimpin, minimal memimpin dirinya sendiri. Setiap pemimpin diminta pertanggungjawaban atas kepemimpinannya. Kepemimpinan (leadership) berasal dari memimpin (lead). Kata lead berasal dari kata Anglo Saxon yang artinya jalur perjalanan kapal yang mengarahkan pelaut. Kata leader digunakan pada awal tahun 1300-an. Bush (2008:4) menyatakan bahwa pemimpin adalah orang yang menentukan tujuan-tujuan, memotivasi, dan me- nindak bawahannya. Pemimpin adalah orang yang memimpin, memberdayakan guru dan tenaga administrasi sekolah, mewakili sekolah, mengarahkan, memotivasi, dan menginspirasi bawahannya.

Kepemimpinan merupakan objek dan subjek yang menarik dan tidak membosankan untuk dipelajari, diteliti, ditulis, didiskusikan, dan direfleksikan baik orang awam, akademisi, maupun praktisi karena aspek dinamis yang terkandung di dalamnya. Kepemimpinan merupakan 
urusan semua orang. Kepemimpinan dalam zaman yang terus berubah harus ditemukan, diinterpretasikan, dan dihidupkan sesuai konteks ruang dan waktunya. Konteksnya adalah model kepemimpinan Kepala SMK DIY dan waktunya yaitu dari Januari sampai Desember 2014.

Seseorang dipilih menjadi pemimpin karena ia memiliki kelebihan tertentu di kelompoknya dan mendapat kepercayaan dari bawahannya. Seseorang yang tidak dipercaya sulit menjadi pemimpin. Pemimpin dipercaya bawahannya karena kejujurannya. Pemimpin dapat bersifat formal dan nonformal. Pemimpin formal ialah pemimpin yang diangkat dengan surat keputusan (SK). Pemimpin nonformal ialah pemimpin yang diangkat kelompoknya tanpa SK. Pemimpin nonformal dapat pula terjadi karena seseorang mengangkat dirinya di saat keadaan darurat atau genting. Pemimpin berbeda dengan pimpinan.

Pimpinan adalah posisi atau jabatan atau orang yang memiliki kedudukan tertinggi dalam suatu organisasi. Pimpinan tertinggi di sekolah disebut kepala sekolah (principal atau head master). Pimpinan berbeda dengan kepemimpinan (leadership).

Kata leadership pertama kali muncul pada tahun 1700-an. Sejak 1993, sudah terdapat 221 definisi kepemimpinan yang ditulis di dalam 587 publikasi ilmiah. Pada tahun 2005, Amazon.com telah mendaftar 18.299 buku kepemimpinan. Google Schoolar mendaftar 16.800 buku kepemimpinan dan sekitar 386.000 kutipan kepemimpinan (Bass \& Bass, 2011). Kepemimpinan didefinisikan orang sesuai sudut pandang masing-masing. Meskipun sudah banyak definisi kepemimpinan, tetapi tidak satupun memuaskan semua orang.

Pada tahun 1920-an, kepemimpinan didefinisikan sebagai kemampuan memengaruhi bawahan agar menjadi taat, hormat, setia, dan mudah bekerja sama (Gill, 2009). Definisi ini adalah definisi yang paling lama dan menjadi dasar bagi definisi kepemimpinan berikutnya. Stogdill (1974) mendefinisikan kepemimpinan sebagai: (1) titik fokus proses kelompok; (2) kepribadian dan pengaruhnya; (3) seni agar bujukan dipenuhi; (4) latihan memengaruhi; (5) tin- dakan atau perilaku; (6) bentuk membujuk; (7) kekuatan hubungan; (8) instrumen mencapai tujuan; (9) suatu pengaruh interaksi; (10) suatu perbedaan peran; dan (11) inisiasi struktur. Definisi kepemimpinan menurut Stogdill tersebut merupakan definisi kepemimpinan yang paling komprehensif.

Definisi kepemimpinan menurut Bush (2008 \& 2011) adalah tindakan memengaruhi orang lain untuk mencapai tujuan akhir yang diharapkan. Pendapat Bush mendapat dukungan Yukl (2010) yang menyatakan bahwa kepemimpinan adalah proses memengaruhi orang lain untuk memahami dan menyetujui kebutuhan yang harus dipenuhi dan cara melakukannya, serta proses memfasilitasi individu dan kelompok dalam mencapai tujuan bersama. Jika Yukl menyatakan kepemimpinan memfasilitasi individu dan sosial, Northouse (2011) menyatakan kepemimpinan adalah proses sosial yang terjadi dalam kelompok yang terlibat dalam mancapai tujuan bersama dan kepemimpinan adalah sifatsifat, kemampuan, keterampilan, perilaku, dan hubungan manusia. Pendapat Northouse tersebut akhirnya dilengkapi oleh Bass \& Bass (2011) dan Hoy \& Miskel (2013).

Bass \& Bass (2011) mendefinisikan kepemimpinan sebagai interaksi dua orang atau lebih dalam suatu kelompok terstruktur terhadap situasi persepsi dan harapan anggota. Hoy \& Miskel (2013: 426) menyatakan, "We define leadership broadly as a social process in which an individual or a group influences behavior toward a shared goal." Kepemimpinan sekolah menurut Smith \& Piele (2012), "The activity of mobilizing and empowering others to serve the academic and related needs of students with utmost skill and integrity." Kepemimpinan sekolah adalah kegiatan menggerakkan dan memberdayakan orang lain untuk memberikan pelayanan akademik sesuai dengan kebutuhan siswa, termasuk keterampilan dan integritas siswa. Dari sembilan definisi kepemimpinan tersebut, dapat disimpulkan bahwa yang disebut dengan kepemimpinan adalah proses memengaruhi orang lain untuk mencapai tujuan secara efektif dan efisien. Kepemimpinan dapat ditinjau dari 
kronologis perkembangan teorinya dan modelmodelnya.

Model menurut Silverman (2014:112), "An overall framework for looking at reality (e.g. positism, constructionism). Model adalah perilaku kepala sekolah yang paling sering muncul selama penelitian ini dilakukan. Sampai saat ini, minimal terdapat 11 model kepemimpinan pendidikan, yaitu: (1) manajerial; (2) partisipatif; (3) transformasional; (4) distributed; (5) transaksional; (6) post modern; (7) emosional; (8) kontingensi; (9) moral; (10) instruksional; dan (11) kewirausahaan (Bush, 2011). Meskipun banyak model kepemimpinan ditemukan para ahli kepemimpinan, tidak ada satupun model kepemimpinan yang terbaik yang dapat diterapkan dalam berbagai situasi karena setiap model memiliki kelebihan dan kelemahan masing-masing.

Pada kesempatan ini, sengaja dipilih model kepemimpinan instruksional karena (1) relevan dengan bidang keahlian peneliti; (2) sekolah merupakan tempat belajar, sebagai konsekuensi logisnya, maka kepemimpinan yang cocok, yaitu kepemimpinan instruksional; (3) kepemimpinan instruksional model SMK DIY belum pernah diteliti; (4) kepemimpinan instruksional merupakan kepemimpinan kepala sekolah di masa yang akan datang (Whitehead, et al. (2014); (5) kepemimpinan instruksional merupakan komponen terpenting dalam meningkatkan proses dan hasil belajar siswa (Hammond, et al. 2010; Bush, 2011); (6) kepemimpinan instruksional merupakan salah satu komponen penilaian kinerja kepala sekolah; (7) kepemimpinan instruksional merupakan kompetensi kepala yang paling rendah dan perlu ditingkatkan (Kompas, 19 Maret 2015 dan 8 Agustus 2015); (8) peran kepala sekolah abad 21 menurut Ano$\operatorname{nim}(2012: 19)$, "The principal's role has changed from 'bells, building, and buses' to one of instructional leadership"; (9) Educational Leadership Constituent Council (ELCC) yang beranggotakan 10 organisasi pendidikan nasional termasuk Amerika Serikat memiliki tujuh standar kepala sekolah. Dari tujuh standar kepala sekolah ternyata enam standar mengandung pemimpin pendidikan; dan (10) Interstate School
Leaders Licensure Consorsium (ISLLC) menekankan pentingnya kepemimpinan instruksional (Schleicher, 2012:23). Kepemimpinan pembelajaran (instructional leadership) disebut juga education leadership, school leadership, visionary leadership, teaching-learning leadership, and supervision leadership (Huber, 2010).

Berkenaan dengan pengertian kepemimpinan instruksional, Heck \& Hallinger (2010: 656) menyatakan, "Conceptualize instructional leadership as 'an organizational property' aimed at school improvement." Kepemimpinan instruksional menurut Bush (2011:17), "Instructional leadership focusses on teaching and learning and on the behavior of teachers in working with students. Leader's influences is targeted at students learning via teachers." Kepemimpinan instruktional menurut Whitehead, et al. (2013: 41) seperti berikut.

- Instructional leader: The principal was expected to serve as an instructional leader, guiding teachers toward productive learning experiences.

- Problem solver and resources provider. The principal was responsible to solve problems and resources to facilates the teaching and learning process.

- A visionary leader. The principal was expected to develop and communicate an image of the ideal school.

- A change agent. The principal was expected to facilate needed changes in educational operations to ensure effectiveness.

Haris (2014:10) meyatakan, "It seems that instructional leadership is little more than a shorthand way of describing those leadership influences and practice within an organization that impact upon student achievement." Pendapat-pendapat para ahli tentang kepemimpinan instruksional pada hakikatnya terdapat persamaan, yaitu fokus pada proses dan hasil belajar siswa melalui guru. Perbedaannya hanyalah terletak pada redaksionalnya saja. Berdasarkan pendapat-pendapat di atas, dapat disimpulkan bahwa kepemimpinan instruksional adalah kepemimpinan yang fokus pada proses dan hasil belajar siswa melalui pemberdayaan guru secara profesional. Hasil penelitian Hammond, et 
al. (2010) ditemukan bahwa terdapat dua cara pemimpin memengaruhi hasil belajar siswa: (1) melibatkan praktik kepemimpinan langsung memengaruhi pembelajaran; dan (2) melibatkan praktik kepemimpinan tidak langsung memengaruhi pembelajaran.

\section{METODE}

Penelitian ini menggunakan pendekatan kualitatif dengan jenis multikasus. Jenis penelitian ini dipilih karena peneliti ingin mendapatkan model berdasarkan kasus yang terjadi di lapangan (Cresswell, 2014). Selanjutnya, peneliti menemukan model kepemimpinan instruksional dalam rangka meningkatkan proses dan hasil belajar siswa.

Tempat penelitian adalah SMKN 2 Pengasih dan SMKN 2 Wonosari Daerah Istimewa Yogyakarta. Kedua tempat tersebut dipilih karena: (1) kedua SMK tersebut telah terbukti tertinggi mutu pembelajaran di SMK DIY; (2) kedua sekolah sudah terakreditasi A; (3) kedua SMK merupakan sekolah favorite di DIY; (4) kedua Kepala SMK berprestasi tingkat kabupaten di DIY; (5) kedua Kepala SMK sudah pernah mengikuti Bimbingan Teknis (Bimtek) Implementasi Kurikulum 2013 dan materi kepemimpinan instruksional merupakan salah satu topik yang dibimtekkan; dan (6) kedua Kepala SMK sudah menerapkan hasil bimtek kepemimpinan instrksional. Waktu penelitian dimulai awal Januari sampai akhir Desember 2014 ata 12 bulan efektif. Subjek penelitian ialah Kepala SMKN yang sudah dapat membuktikan profesionalisme mereka.

Teknik pengumpulan data menggunakan wawancara mendalam, kemudian di-cross check dengan observasi partisipatif dan dokumentasi. Instrumen penelitian adalah peneliti sendiri $(h u-$ man instrument). Teknik sampel yang digunakan snowball sampling, artinya responden bertambah terus dan tidak dapat ditetapkan jumlah sampai diperoleh data yang jenuh (redundancy). Data yang dikumpulkan mengacu pada pertanyaan penelitian.

Jenis data yang dikumpulkan adalah data kualitatif berupa kata-kata dalam bentuk deskripsi, walaupun tidak menutup kemungkinan data berupa angka sebagai pendukung data kualitatif.

Wawancara mendalam dilakukan dengan key informant. Catatan selama penelitian disebut catatan lapangan. Setiap data yang diperoleh dari satu informan dilakukan cross check dengan informan yang lain sehingga data dan informasi yang didapat relatif objektif. Subjek bertambah terus seperti bola salju (snowball). Data dikumpulkan sampai tidak ada lagi pertanyaan baru atau data sudah jenuh (redundan$c y)$. Artinya, data sudah tidak dapat berubah lagi. Jadi, jumlah sumber data ada sembilan orang.

Hasil wawancara terhadap key informan kemudian dicek dengan menggunakan pengamatan langsung dan teknik dokumentasi. Teknik dokumentasi dilakukan peneliti dengan cara mengumpulkan bukti fisik yang tercetak, terekam, tercatat yang mendukung hasil wawancara dan pengamatan langsung sehingga didapat data yang dapat objektif dan dapat dipertanggungjawabkan.

Teknik pemeriksaan atau pengujian pada tingkat kepercayaan hasil sangat diperlukan untuk menentukan keabsahan data. Keabsahan data dilakukan dengan kriteria: (1) kredibilitas; (2) transferabilitas; (3) dependabilitas; dan (4) komfirmabilitas atau kepastian (objektivitas).

Agar penelitian ini kredibel, tim peneliti melakukan: (1) waktu yang digunakan dalam penelitian harus relatif lama, yaitu sekitar satu tahun; (2) pengamatan dilakukan secara terusmenerus, yaitu tim peneliti ke lapangan secara rutin setiap dua minggu sekali berkunjung ke SMK Negeri 2 Pengasih dan SMKN 2 Wonosari untuk melakukan observasi, wawancara, dan mencari dokumentasi yang relevan; (3) mengadakan triangulasi, yaitu mengecek jawaban kepala sekolah ke wakil kepala sekolah bidang kurikulum dan salah satu guru yang dapat dipercaya; (4) mendiskusikan dengan teman seprofesi, yaitu tim mengadakan diskusi terhadap data yang didapat; (5) menganalisis kasus negatif, yaitu mengecek kembali mengapa ada jawaban responden yang bertentangan dengan kepala sekolah sebagai key informan; (6) menggunakan alat-alat bantu dalam mengumpulkan data yaitu menggunakan catatan lapangan (field 
note, tustel, tape recorder); dan (7) menggunakan member check, yaitu mengecek informasi ke anggota sekolah lainnya..

Transferabilitas terjadi apabila hasil penelitian ini dapat diterapkan pada SMK lain yang tidak menjadi tempat penelitian. Transferabilitas bergantung pada karakteristik tempat hasil penelitian ini akan diterapkan. Transferabilitas hanya terjadi jika karakteristik tempat menerapkan hasil penelitian relatif sama atau hampir sama dengan tempat penelitian ini.

Depandabilitas adalah apabila hasil penelitian memberikan hasil yang sama dengan penelitian yang diuji pihak lain. Untuk dapat membuat penelitian kualitatif memenuhi depandabilitas, proses penelitian kualitatif harus diaudit oleh auditor independen agar dapat memenuhi kriteria dependabilitas dalam hal ini oleh Tim Reviewer Program Pascasarjana. Tim re- viewer-lah yang berhak memeriksa kebenaran data serta penafsirannya.

Konfirmabilitas adalah kriteria untuk menilai kualitas hasil penelitian dengan perekaman pada pelacakan data dan informasi serta interpretasi yang didukung oleh materi yang ada pada penelusuran atau pelacakan audit (audit trail). Peneliti harus menyiapkan bahan-bahan yang diperlukan untuk memudahkan tim reviewer melakukan penelusuran atau pelacakan audit (audit trail). Adapun bahan-bahan yang harus disiapkan adalah: (1) data mentah; (2) hasil analisis data; dan (3) hasil sintesa data, yaitu: tafsiran, kesimpulan, tema, model, hubungan dengan kepustakaan, dan laporan akhir. Analisis data dalam penelitian ini dilakukan dengan model Cresswell (2014) seperti Gambar 1. Cara pengkodean (coding) data menggunakan model MacMillan dengan langkah-langkah seperti Gambar 2.

Intepreting the Meaning of the Themes/Description

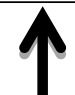

Intepreting Themes/Description (e.g.: Grounded Theory, Case Study

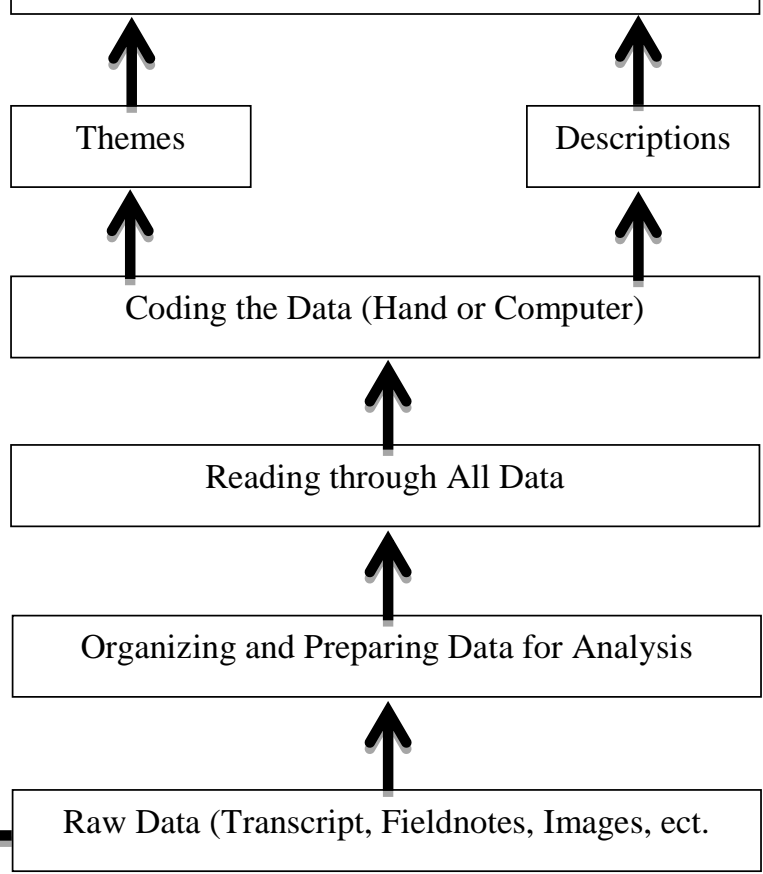

Raw Data (Transcript, Fieldnotes, Images, ect.

Gambar 1. Analisis Data dalam Penelitian Kualitatif (Creswell, 2014:197) 


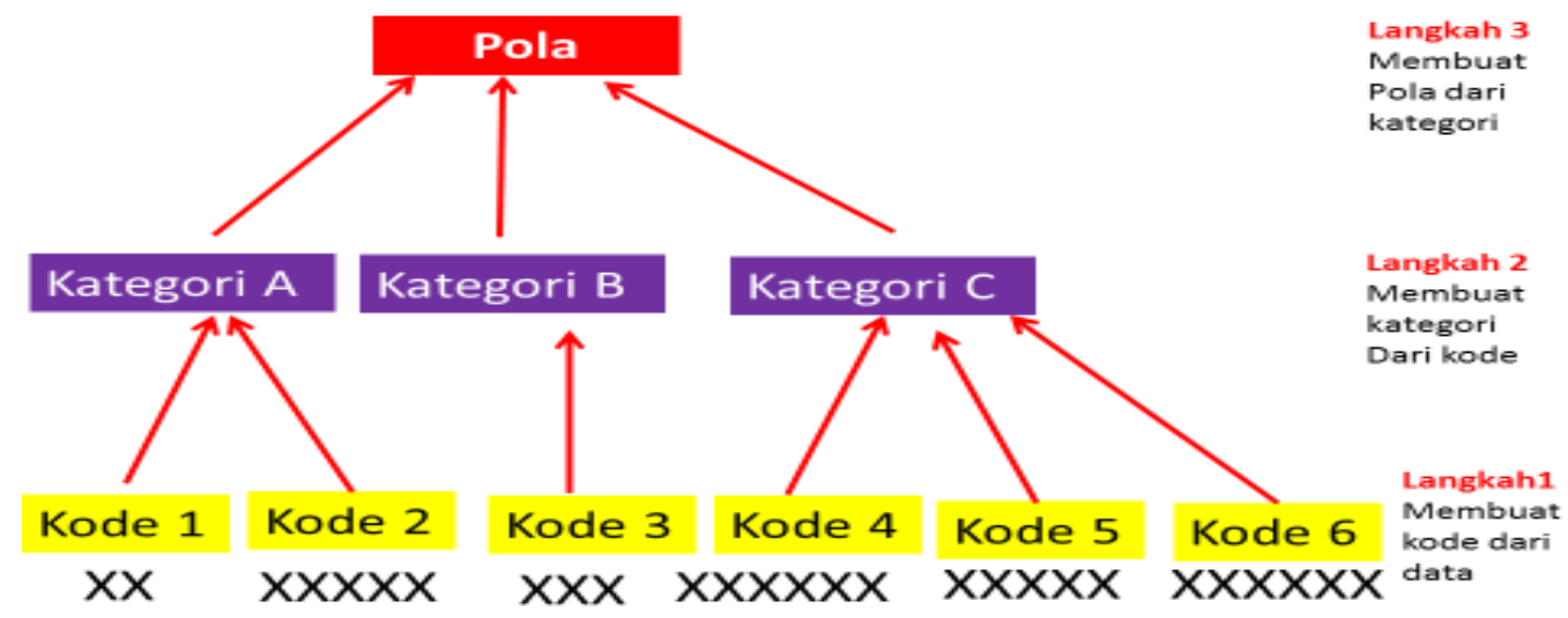

Gambar 2. Cara Pengkodean Data dan Kategorisasi (McMillan, 2013: 297)

\section{HASIL DAN PEMBAHASAN}

Pengumpulan data melalui wawancara mendalam berkali-kali dilakukan dengan Kepala SMKN 2 Pengasih dan hasilnya dicek dengan Wakil Kepala Sekolah Bidang Kurikulum dan salah seorang guru favorit di SMKN 2 Pengasih. Demikian pula kegiatan pengumpulan data yang sama dilakukan dengan Kepala SMKN 2Wonosari dan hasilnya dicek dengan Wakil Kepala Sekolah Bidang Kurikulum dan salah seorang guru favorit di SMKN 2 Wonosari sampai jawabannya jenuh (jawabannya relatif bermakna sama). Hasil wawancara dicek dengan pengamatan langsung terhadap kegiatan Kepala SMKN 2 Pengasih dan Kepala SMKN 2 Wonosari dalam kegiatan kepemimpinan instruksional. Selain itu, juga dikonfirmasi lagi dengan dokumentasi tentang kepemimpinan instruksional yang ada di SMKN 2 Pengasih dan SMKN 2 Wonosari.

\section{Pemahaman Kepala SMKN 2 Pengasih ter- hadap Definisi Kepemimpinan Instruksional}

Hasil wawancara mendalam berulang kali dengan Kepala SMKN 2 Pengasih dapat disimpulkan bahwa kepemimpinan instruksional adalah pendampingan terlaksanaannya proses belajar mengajar yang meliputi kegiatan: perencanaan, pelaksanaan, dan evaluasi pembelajaran agar dapat meningkatkan proses dan hasil belajar siswa. Hasil observasi langsung menunjukkan bahwa kepala sekolah melakukan pendampingan dengan terlebih dahulu melakukan sosialisasi pembuatan Rencana Pelaksanaan Pelajaran (RPP), memberi contoh cara membuat RPP yang baik, dan menugaskan setiap guru membuat RPP. Hasil observasipartisipasi terhadap kepemimpinan insruksional Kepala SMKN 2 Pengasih menunjukkan bahwa ada permintaan kepala sekolah agar semua guru membuat RPP sesuai dengan sosialisasi dan konsultasi dengan kepala sekolah. RPP yang telah dibuat guru, selanjutnya diperiksa, dan yang belum baik direvisi kembali oleh guru, sampai akhirnya ditandatangani kepala sekolah. RPP semua guru telah terdokumentasi dengan baik di dalam stopmap khusus RPP.

\section{Pemahaman Kepala SMKN 2 Wonosari ter- hadap Definisi Kepemimpinan Instruksional}

Hasil wawancara mendalam berulang kali dengan Kepala SMKN 2 Wonosari dapat disimpulkan bahwa kepemimpinan pembelajaran adalah kepemimpinan yang fokus pada pelaksanaan kurikulum, pengembangan guru, proses pembelajaran, evaluasi terhadap peningkatan mutu proses dan hasil pembelajaran siswa. Hasil observasi partisipasi terhadap pelaksanaan 
kepemimpinan instruksional menunjukkan bahwa Kepala SMKN 2 Wonosari meminta semua guru membuat RPP sesuai ketentuan yang berlaku, selanjutnya RPP tersebut diperiksa, direvisi guru, sampai mendapat persetujuan dan tanda tangan kepala sekolah. Semua RPP guru diarsipkan oleh Pelaksana Urusan Kurikulum dan Pembelajaran dalam bentuk soft ware (gerti) dan hard ware (dicetak dan dijilid) yang ditempatkan pada tempat khusus arsip RPP.

Persamaan kedua temuan definisi kepemimpinan insruksional di atas adalah keduanya sependapat bahwa kepemimpinan instruksional adalah kepemimpinan yang fokus pada proses dan hasil belajar siswa melalui pemberdayaan guru secara profesional. Perbedaannya adalah jika Kepala SMKN 2 Pengasih menganggap proses PBM sama dengan manajemen pembelajaran dan kepemimpinan adalah memengaruhi orang lain, maka Kepala SMKN 2Wonosari mendefinisikan kepemimpinan pembelajaran yang fokus pada kurikulum, pembelajaran, pengembangan staf, supervisi pembelajaran, program pembelajaran, evaluasi program guru dan siswa, penelitian tindakan, dan peningkatan mutu, dan proses pembelajaran secara terus-menerus. Karena fokusnya lebih rinci atau lebih banyak sehingga terkesan menjadi tidak tidak fokus lagi.

Definisi kepemimpinan instruksional ini perlu ditemukan agar semua pihak dapat memahami dan menyamakan persepsi tentang kepemimpinan instruksional sehingga bagi yang menerapkannya di sekolah memiliki model pikir, model rasa, dan model tindak yang sama. Kedua temuan definisi kepemimpinan instruksional di atas ternyata mendukung pendapat Heck \& Hallinger (2010: 656), Bush (2011: 17), Whitehead, et al. (2013:41), dan Haris (2014:10) seperti yang telah diungkapkan pada Pendahuluan di atas. Adanya kesamaan temuan penelitian dengan pendapat para ahli tersebut karena kedua kepala sekolah pernah menerima materi kepemimpinan instruksional dalam Bimtek Implementasi Kurikulum 2013 yang berisikan tentang definisi kepemimpinan instruksional. Perbedaan temuan definisi kepemimpinan instruksional dengan para ahli tersebut hanyalah terletak pada redaksionalnya saja.

Kedua temuan definisi kepemimpinan instruksional mendukung penelitian Robertson \& Timperley (2011:58) bahwa kepemimpinan kepala sekolah memengaruhi prestasi belajar siswa melalui guru. Hasil penelitian Leitwood, et al. (2004:18\& 2010:14) menemukan bahwa kepemimpinan kepala sekolah berpengaruh tidak langsung terhadap hasil belajar siswa, tetapi melalui guru. Temuan kedua definisi kepemimpinan instruksional mendukung penelitian Supriyo (2015:33) yang menyimpulkan bahwa secara keseluruhan, kepemimpinan kepala sekolah, iklim kerja, pelatihan, kompetensi, dan kepuasan kerja berpenagruh terhadap motivasi kerja guru (89\%). Dukungan tersebut terjadi karena kepemimpinan kepala sekolah pada penelitian Supriyo dan kepemimpinan instruksional pada penelitian ini sama-sama meningkatkan hasil belajar siswa melalui motivasi guru dalam mengajar siswanya karena hasil belajar siswa tidak langsung dari kepemimpinan instruksional kepala sekolah, tetapi melalui guru yang memiliki motivasi tinggi. Perbedaan penelitian ini dengan penelitian Supriyo adalah jika penelitian ini menggunakan pendekatan kualitatif, maka penelitian Supriyo meggunakan pendekatan kuantitatif.

\section{Pendapat Kepala SMKN 2 Pengasih tentang Tujuan dan Manfaat Kepemimpinan Ins- truksional}

Hasil wawancara mendalam dengan Kepala SMKN 2 Pengasih dapat disimpulkan bahwa tujuan kepemimpinan instruksional adalah terwujudnya peningkatan mutu proses dan hasil belajar siswa secara terus-menerus. Manfaat kepemimpinan instruksional adalah: (1) meningkatnya hasil belajar siswa; dan (2) meningkatnya kinerja guru. Hasil observasi partisipasi menunjukkan bahwa nilai ujian harian, ujian sekolah, dan ujian nasional dari tahun ke tahun mengalami peningkatan terus-menerus. Guru tertib administrasi dalam penyelesaian RPP untuk seluruh mata pelajaran. Motivasi mengajar guru dan motivasi belajar siswa meningkat. Kinerja dan kepuasan guru meningkat. Monev 
pembelajaran berlangsung secara priodik. Data dokumentasi hasil belajar siswa meningkat secara terus-menerus.

\section{Pendapat Kepala SMKN 2 Wonosari tentang Tujuan dan Manfaat Kepemimpinan Ins- truksional}

Hasil wawancara mendalam dengan $\mathrm{Ke}-$ pala SMKN 2 Wonosari dapat disimpulkan bahwa tujuan kepemimpinan instruksional adalah terfokusnya guru pada peningkatan mutu proses dan hasil belajar siswa. Manfaat kepemimpinan instruksional adalah: (1) meningkatnya mutu proses belajar siswa; dan (2) meningkatnya prestasi kerja guru.

Tujuan kepemimpinan instruksional perlu ditemukan dalam penelitian ini agar semua pihak yang terlibat dalam melaksanakan kepemimpinan instruksional mengetahui dengan jelas tujuan yang akan dicapai. Semua pihak yang terlibat memiliki kesamaan langkah dalam mencapai tujuan. Tujuan yang jelas memberikan arah bagi pihak terlibat untuk bertindak dan meningkatkan motivasi untuk mencapainya. Demikian pula manfaat kepemimpinan instruksional perlu ditemukan dalam penelitian ini karena tanpa manfaat yang jelas membuat semua usaha kepemimpinan instruksional menjadi mubazir dan sia-sia belaka.

Manfaat kepemimpinan instruksional menurut Kepala SMKN 2 Pengasih berbeda dengan manfaat kepemimpinan instruksional menurut Kepala SMKN 2 Wonosari. Tujuan kepemimpinan instruksional yang kedua maknanya sama hanya pemilihan katanya yang berbeda. Jika Kepala SMKN 2 Pengasih menggunakan untuk meningkatkan prestasi kerja, maka Kepala SMKN 2 Wonosari menggunakan istilah meningkatkan kinerja.

Temuan penelitian ini berbeda dengan manfaat kepemimpinan menurut Gorton et al. (2007), yaitu sebagai sarana untuk: (1) menerapkan dan mengembangkan visi; (2) melakukan perubahan terutama meningkatkan mutu sekolah terus-menerus; (3) mengembangkan sekolah dan menjadi sekolah efektif; (4) mendapatkan kepemimpinan yang efektif; (5) memberdayakan guru dan tenaga kependidikan: (6) me- nerapkan dan mengembangkan iklim dan budaya sekolah yang kondusif; (7) mendapatkan simbol sekolah, yaitu orang pertama yang mewakili sekolah; (8) mendemonstrasikan keterampilan, ganjaran, dukungan, sistem, pengelolaan sumber daya, pembuatan keputusan, pendelegasian, komunikasi, koordinasi, kerja sama, dan situasi; dan (9) meningkatkan daya saing saing sekolah. Perbedaan temuan penelitian ini dengan pendapat Gorton, et al. terjadi karena penelitian ini mengkhususkan diri pada kepemimpinan instruksional, sedangkan Gorton et al. (2007) memandang kepemimpinan pendidikan dalam arti luas.

Temuan manfaat kepemimpinan instruksional dapat atau memengaruhi kinerja guru mendukung penelitian Werang (2014:135) yang menyimpulkan bahwa kepemimpinan transformasional kepala sekolah berpengaruh secara signifikan terhadap kinerja guru. Dukungan ini terjadi karena baik kepemimpinan transformasional maupun kepemimpinan instruksional, keduanya sama-sama melakukan perubahan ke arah yang lebih baik antara lain meningkatkan kinerja guru.

\section{Pendapat Kepala SMKN 2 Pengasih tentang Indikator Kepemimpinan Instruksional yang Efektif}

Hasil wawancara mendalam dengan Kepala SMKN 2 Pengasih disimpulkan bahwa indikator kepemimpinan pembelajaran yang efektif adalah: (1) merumuskan konsep dan strategi pelaksanaan; (2) menetapkan target yang akan dicapai; (3) konsisten terhadap peningkatan mutu; dan (4) terus berusaha melakukan perbaikan berkelanjutan. Hasil observasi partisipasi menunjukkan bahwa kepala sekolah meminta guru mencapai indikator kepemimpinan instuksional yang efektif di atas. Hasil dokumentasi menunjukkan bahwa beberapa indikator pembelajaran yang efektif tampak pada Rencana Kerja Sekolah (RKS) dan Rencana Kegiatan dan Anggaran Sekolah (RKAS) dan dibiayai oleh RAPBS. 


\section{Pendapat Kepala SMKN 2 Wonosari tentang Indikator Kepemimpinan Instruksional yang Efektif}

Hasil wawancara mendalam dengan $\mathrm{Ke}$ pala SMKN 2 Wonosari dapat disimpulkan bahwa indikator kepemimpinan instruksional yang efektif adalah: (1) menetapkan strategi pembelajaran; (2) menetapkan target; dan (3) meningkatnya mutu proses dan hasil belajar siswa secara kontinyu. Hasil observasi partisipasi tentang indikator kepemimpinan instruksional $\mathrm{Ke}$ pala SMKN 2 Wonosari ditunjukkan oleh tindakan kepala sekolah yang meminta semua guru mencapai indikator kepemimpinan instruksional yang efektif seperti di atas. Hasil dokumentasi menunjukkan bahwa indicator kepemimpinan instruksional yang efektif dicapai melalui RKS. RKAS, dan RAPBS.

Indikator kepemimpinan instruksional perlu ditemukan dalam penelitian ini agar semua pihak yang menerapkan kepemimpinan instruksional memiliki target yang jelas untuk dicapai. Indikator yang baik seharusnya dapat diukur dan atau dapat diamati dengan baik. Indikator yang dapat diukur mengandung angka, sedangkan indikator yang dapat diamati dapat dilihat dengan mata tanpa bias.

Persamaan kedua temuan di atas adalah keduanya memiliki tiga indikator kepemimpinan instruksional yang efektif. Kedua temuan memiliki makna yang sama. Konsisten terhadap peningkatan mutu menurut Kepala SMKN 2 Pengasih sama maknanya dengan meningkatkan mutu secara kontinyu menurut Kepala SMKN 2 Wonosari. Perbedaannya adalah Kepala SMKN 2 Pengasih menambah indikator konsisten terhadap peningkatan mutu.

Temuan indikator kepemimpinan instruksional kedua kepala sekolah adalah: (1) merumuskan konsep dan strategi pelaksanaan; (2) menetapkan strategi; (3) menetapkan target (indikator) yang akan dicapai; dan (4) konsisten berusaha meningkatkan mutu proses dan hasil belajar siswa secara kontinyu. Kedua temuan di atas ternyata berbeda dengan temuan penelitian Organization for Economic Co-operation and Development (OECD) (Anonim, 2009) yang menyatakan bahwa ciri-ciri (karakteristik) kepe- mimpinan instruksional yang efektif yaitu: (1) memantau kinerja guru terus-menerus; (2) menilai kinerja guru; (3) melaksanakan dan mengatur pendampingan dan pelatihan guru; (4) merencanakan PKB guru; (5) mengkoordinasikan kerja tim; dan (6) mengkoordinasikan pembelajaran kolaboratif. Perbedaan temuan penelitian ini dengan hasil penelitian OECD karena penelitian dilakukan di negara anggota OECD, sementara Indonesia bukan anggota OECD.

Temuan penelitian ini berbeda dengan temuan Fanani (2013) seperti yang tercantum pada pendahuluan di atas. Perbedaan ini terjadi karena penelitian Fanani meneliti model asesmen kepemimpinan instruksional Kepala SD di Banjarmasin dengan pendekatan kuantitatif, sedangkan penelitian ini meneliti model kepemimpinan instruksional Kepala SMKN 2 Pengasih dan SMKN 2 Wonosari dengan pendekatan kualitatif.

\section{Strategi Kepemimpinan Instruksional di SMKN 2 Pengasih}

Hasil wawancara mendalam dengan Kepala SMKN 2 Pengasih dapat disimpulkan bahwa strategi kepemimpinan instruksional menurut Kepala SMKN 2 Pengasih adalah: (1) keteladanan; (2) pembelajaran di kelas dan luar kelas; (3) iklim kondusif; (4) budaya kondusif; (5) penguatan kepemimpinan kepala sekolah; (6) kepala sekolah menjadi model (7) banyak berdiskusi dengan guru tentang peningkatan mutu pembelajaran; dan (8) mendampingi guru. Hasil observasi partisipasi tentang strategi kepemimpinan instruksional ditunjukkan dengan adanya keteladanan kepala sekolah dalam mebuat RPP bagi guru-gurunya.

\section{Strategi Kepemimpinan Instruksional di SMKN 2 Wonosari}

Hasil wawancara mendalam dengan Kepala SMKN 2 Wonosari dapat disimpulkan bahwa strategi kepemimpinan instruksional menurut Kepala SMKN 2 Wonosari adalah: (1) menetapkan sasaran mutu; (2) membuat program pelaksanaan kegiatan untuk mencapai sasaran mutu; (3) monev peaksanaan program; dan (4) menindaklanjuti hasil monev. Hasil 
observasi partisipasi tentang strategi kepemimpinan instruksional ditunjukkan dengan tindakan kepala sekolah melakukan strategi kepemimpinan instruksional seperti yang telah dinyatakan di atas.

Kedua temuan di atas berbeda dalam jumlah dan substansi strateginya. Perbedaan ini terjadi karena masing-masing Kepala SMK memiliki pilihannya masing-masing dan memilih yang dianggap mudah, cepat, dan ekonomis menurut persepsi masing-masing. Temuan penelitian di atas ternyata mendukung pendapat Bush (2008:23) yang menyatakan strategi kepemimpinan pembelajaran adalah dengan melakukan: modelling, discuss with teacher, and mentoring.

\section{Cara Praktis Kepala SMKN 2 Pengasih Me- laksanakan Kepemimpinan Instruksional}

Hasil wawancara mendalam dengan Kepala SMKN 2 Pengasih dapat disimpulkan bahwa cara praktis melakukan kepemimpinan instruksional adalah: (1) melaksanakan persiapan administrasi pembelajaran; (2) memotivasi siswa; (3) memberikan materi pembelajaran; (4) membuat jadwal pelajaran; (5) melaksanakan monev proses pembelajaran di kelas secara periodik; dan (6) memberikan rekomendasi bagi guru yang dimonev untuk perbaikkan.Hasil observasipertisipasi tentang cara melakukan kepemimpinan instruksional Kepala SMKN 2 Pengasih ditunjukkan dengan melakukan kepemimpinan instruksional dengan cara di atas.

\section{Cara Praktis Kepala SMKN 2 Wonosari Me- laksanakan Kepemimpinan Instruksional}

Hasil wawancara mendalam dengan Kepala SMKN 2 Wonosari dapat disimpulkan bahwa cara praktis Kepala SMKN 2 Wonosari melakukan kepemimpinan instruksional adalah: (1) menetapkan sasaran mutu; (2) membuat program pelaksanaan kegiatan untuk mencapai sasaran mutu, (3) monev pelaksanaan program; (4) menindaklanjuti hasil evaluasi. Hasil observasi partisipasi tentang cara melakukan kepemimpinan instruksional Kepala SMKN 2 Wonosari ditunjukkan dengan tindakannya memberi keteladan- an kepada semua guru untuk melakukan kepemimpinan instruksional dengan cara di atas.

Temuan penelitian ini mendukung tiga cara praktis melaksanakan kepemimpinan instruksional yang efektif menurut Willison (2010) yaitu: banyak berdialog dengan guru, sering berkunjung ke kelas, dan memfasilitasi guru dalam mengajar. Temuan penelitian ini mendukung cara praktis melaksanakan kepemimpinan instruksional yang dilakukan oleh Levin (2012:177), yaitu kepala sekolah: (1) menetapkan visi dan tujuan belajar (mengacu standar kompetensi lulusan); (2) membangun tim kerja yang kuat (termasuk menilai dan meningkatkan kinerja guru); (3) mewujudkan dan mendukung budaya sekolah yang kondusif;(4) mengomunikasikan visi belajar, mengarahkan cara mencapainya; (5) merekrut, mengembangkan, dan melatih kembali kepala sekolah dan PKB guru; (6) membangun dukungan internal dan eksternal sekolah; (7) memelihara dan tetap fokus pada pembelajaran (melaksanakan supervisi akademik di kelas). Perbedaannya terletak dalam jumlah langkah dan lebih rinci dibandingkan dengan temuan penelitian ini.

Model konseptual kepemimpinan instruksional kepala sekolah ditunjukkan pada Gambar 3.

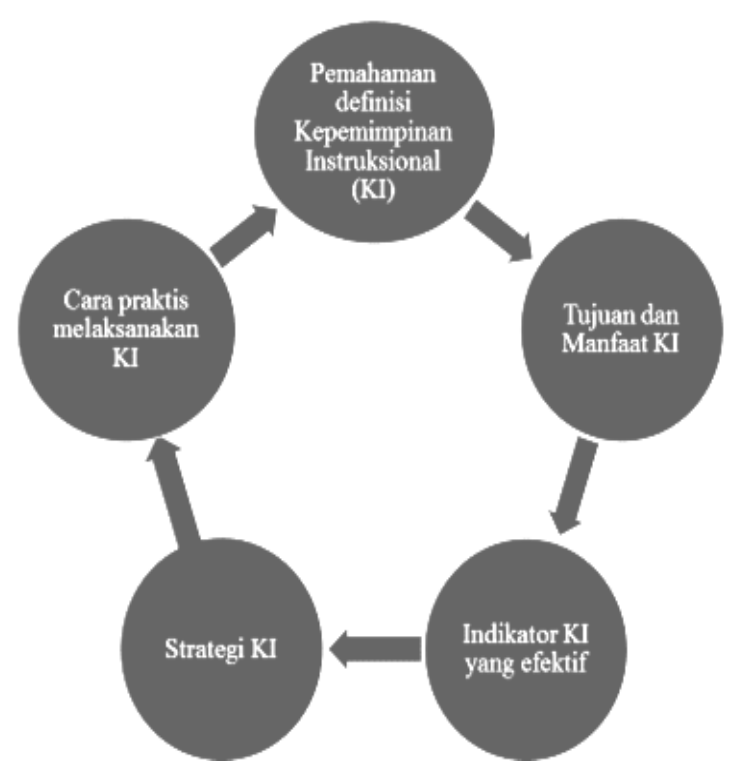

Gambar 3. Model Konseptual Kepemimpinan Instruksional Kepala Sekolah 


\section{PENUTUP}

Berdasarkan uraian hasil penelitian dan pembahasan di atas, dapat disimpulkan hal-hal seperti berikut.

Pertama, kepemimpinan instruksional adalah pendampingan yang fokus pada pembelajaran yang meliputi perencanaan, pelaksanaan, dan evaluasi pembelajaran sesuai kurikulum, dan mengembangkan keprofesionalan guru guru untuk meningkatkan proses dan hasil belajar siswa.

Kedua, tujuan kepemimpinan instruksional adalah: (1) terwujudnya peningkatan mutu proses dan hasil belajar siswa secara terusmenerus; dan (2) terfokusnya guru pada peningkatan mutu proses dan hasil belajar siswa. Manfaat kepemimpinan instruksional adalah: (1) meningkatnya mutu proses dan hasil belajar siswa; dan (2) meningkatnya kinerja guru.

Ketiga, indikator kepemimpinan instruksional yang efektif adalah: (1) merumuskan konsep dan strategi pelaksanaan; (2) menetapkan strategi; (3) menetapkan target yang akan dicapai; dan (4) konsisten berusaha meningkatkan mutu proses dan hasil belajar siswa secara kontinyu.

Keempat, strategi kepemimpinan instruksional adalah: (1) keteladanan; (2) pembelajaran di kelas dan luar kelas; (3) iklim kondusif; (4) budaya kondusif; (5) penguatan kepemimpinan kepala sekolah; (6) kepala sekolah menjadi model; (7) banyak berdiskusi dengan guru tentang peningkatan mutu pembelajaran; (8) mendampingi guru; (9) menetapkan sasaran mutu; (10) membuat program pelaksanaan kegiatan untuk mencapai sasaran mutu; (11) monev pelaksanaan program; dan (12) menindaklanjuti hasil monev.

Kelima, cara praktis kepala sekolah melakukan kepemimpinan pembelajaran adalah: (1) menetapkan sasaran mutu; (2) membuat program pelaksanaan kegiatan untuk mencapai sasaran mutu; (3) melaksanakan persiapan administrasi pembelajaran; (4) memotivasi siswa; (5) memberikan materi pembelajaran; (4) membuat jadwal pelajaran; (6) melaksanakan monev proses pembelajaran di kelas secara periodik; (7) memberikan rekomendasi bagi guru yang dimo- nev untuk perbaikkan; dan (8) menindaklanjuti hasil monev.

\section{UCAPAN TERIMA KASIH}

Penulis mengucapkan terima kasih kepada tim reviu yang telah memberikan masukan untuk merevisi aktikel hasil penelitian ini. Penulis juga mengucapkan terima kasih kepada Redaksi dan Staf Jurnal Cakrawala Pendidikan yang telah memberikan kesempatan untuk memublikasikan artikel hasil penelitian ini.

\section{DAFTAR PUSTAKA}

Anonim. 2009. Improving Educational Leadership: Tool Kit. Paris: OECD.

Anonim. 2012. Teaching and Leadership for The Twenty-First Entury: The 2012 International Summit on Teaching Profession. Paris: OECD \& Asia Society Partnership Global Learning.

Bass, B.M., \& Bass, R. 2011. Handbook of Leadership: Theory, Research, and Management Application. Fouth Edition. New York: Free Press.

Bush, T. 2008. Leadership and Management Development in Education. London: Sage.

Bush, T. 2011. Theories of Educational Leadership and Management. $4^{\text {th }}$ Edition. London: Sage Publications, Ltd.

Creswell, J.W. 2014. Research Design Qualitative, Quantitative, \& Mixed Methods Approach. London: Sage.

Fanani, Zainal. 2013. "Instrumen Kepemimpinan Pembelajaran Kepala Sekolah Dasar". Disertasi Doktor, tidak Ditebitkan, Universitas Negeri Yogyakarta.

Gill, R. 2009. Theory and Practice of Leadership. London: Sage.

Gorton, R., Alston, J.A., \& Snowden, P. 2007. School Leadership \& Administration Im- 
portant Concepts, Case Studies, \& Simulations. Seventh Edition. New York: McGraw Hill.

Harris, A. 2014. Distributed Leadership Matter Perspectives, Practicalities, and Potentials. Thousand Oaks, California: Corwin Sage Company.

Hammond, L.D., Meyerson, D., LaPointe, M., \& Orr, M.T. 2010. Preparing Principals for A Changing World Lessons from Effective School Leadership Programs. San Francisco, CA: Jossey-Bass.

Heck, R., \& Hallinger, P. 2010. "Testing a Longitudinal Model of Distributed Effect on School Improvemen". Leadership Quarterly, 21, pages 867-885.

Hoy, W.K., \& Miskel, C.G. 2013. Educational administration: Theory, Research, and Practice. Ninth Edition. New York: McGraw Hill.

Huber, G.S. 2010. School Leadership International Perspective. London: Springer.

Kepala Sekolah Diuji Kelemahan pada Supervisi. (19 Maret 2015). Kompas, hlm. 11.

Kualitas Kepsek Rendah Perekrutan Kepala dan Pengawas Sekolah Belum Ideal. (8 Agustus 2015). Kompas, hlm. 11.

Leitwood, K., Seashore, L.K., Anderson, S., \& Wahlstrom, K. 2004. How Leadership Influences Student Learning: A Review of Research for The Learning from Leadership Project. New York: The Wallace Foundation.

Levin, B. 2012.How to Change 5000 Schools A Practical and Positive Approach for Leading Change at Every Level. Third Printing. Cambridge, Massachusetts: Harvard University Press.
McMillan, J.H. 2013. Educational Research Fundamentals for the Consumer. New York: Pearson.

Northouse, P.G. 2011. Introduction to Leadership Concepts and Practice. London: Sage.

Robertson, J., \& Timperley, H. (Editor). 2011. Leadership andLearning. London: Sage.

Schleicher, A. 2012. Preparing Teacher and Developing School Leaders for the 21th Century Lessons from Around the World. Paris: OECD Publishing.

Silverman, D. 2014. Doing Qualitative Research. New York: McGraw Hill.

Stogdill, R.M. 1974. Handbook of Leadership: A Survey of Theory and Research. New York: The Free Press.

Supriyo. 2015. "Motivasi Kerja Guru SMP Negeri Kota Semarang". Cakrawala Pendidikan., XXXIV (1), hlm. 24-33.

Smith, C.S., \& Piele, P.K. 2012. School Leadership: Handbook for Excellent in Student Learning. Fourth Edition. Thousand Oak, California: Corwin Press.

Werang, Basilus Redan. 2014. "Pengaruh Kepemimpinan Transformasional Kepala Sekolah, Moral Kerja Guru, dan Kepuasan Kerja terhadap Kinerja Guru SDN di Kota Merauke". Cakrawala Pendidikan, XXXIII (1), hlm. 128-137).

Whitehead, B.M., Bosschee, F., \& Decker, R.H. 2014. The principal Leadership for a Global Society. London: Sage.

Willison, R. 2010. "What Make an Instructional Leader". Phi Dekta Kappan. November, Vol. 92 Nomor 3, page 66-69.

Yulk, Gary. 1998. Leadership in Organizations. London: Prentice-Hall International. 